\title{
Six years of petroleum geological activities in North-East Greenland (2008-2013): projects and a view of the future
}

\author{
Jørgen A. Bojesen-Koefoed, Peter Alsen and Flemming G. Christiansen
}

The deadline for applications to the first licence round for petroleum exploration offshore North-East Greenland was 15 December 2012. The round was restricted, allowing only members of the KANUMAS consortium to be operators (BP, Chevron, Exxon, JOGMEG, Shell and Statoil). Nunaoil is also part of KANUMAS, but it is a carried, non-operator partner. An ordinary licensing round followed shortly after with a deadline on 15 October 2013.

At the end of 2013, pre-round licences were awarded and the results of the ordinary round are expected in 2014. Irrespective of the outcome of future exploration activities, this milestone marks an important step in Greenland's long way towards becoming an oil nation. It also offers an opportunity to summarise petroleum-directed activities in NorthEast Greenland since 2008, through which the Geological Survey of Denmark and Greenland (GEUS) has provided crucial knowledge to both the industry and the Greenland Bureau of Minerals and Petroleum (BMP) in their preparations for the licence rounds.

\section{Background}

Almost a decade ago, a licence round offshore North-East Greenland, including the Danmarkshavn Basin (Figs 1, 2), was discussed between the KANUMAS partners and the $\mathrm{BMP}$, and the details of timing and block locations were negotiated over several years. In keeping with this, GEUS initiated discussions with the petroleum industry to clarify its needs in order to be able to provide optimal service to both companies and authorities when required. Concurrently, the United States Geological Survey's (USGS) 'Circum Arctic Resource Appraisal' directed focus to subjects that required further study. The North-East Greenland part was carried

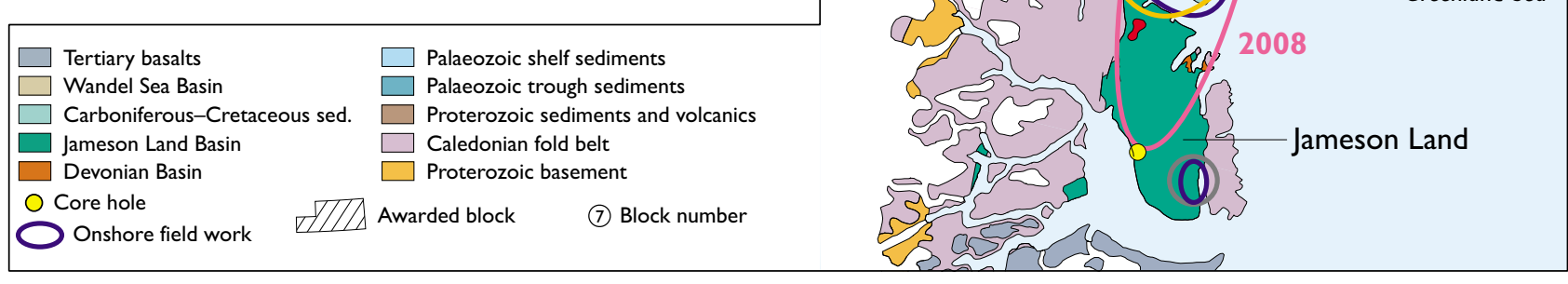

Fig. 1. Map of North-East Greenland, showing the offshore licence area, onshore field work areas (colour-coded according to year) and the locations of core holes. 


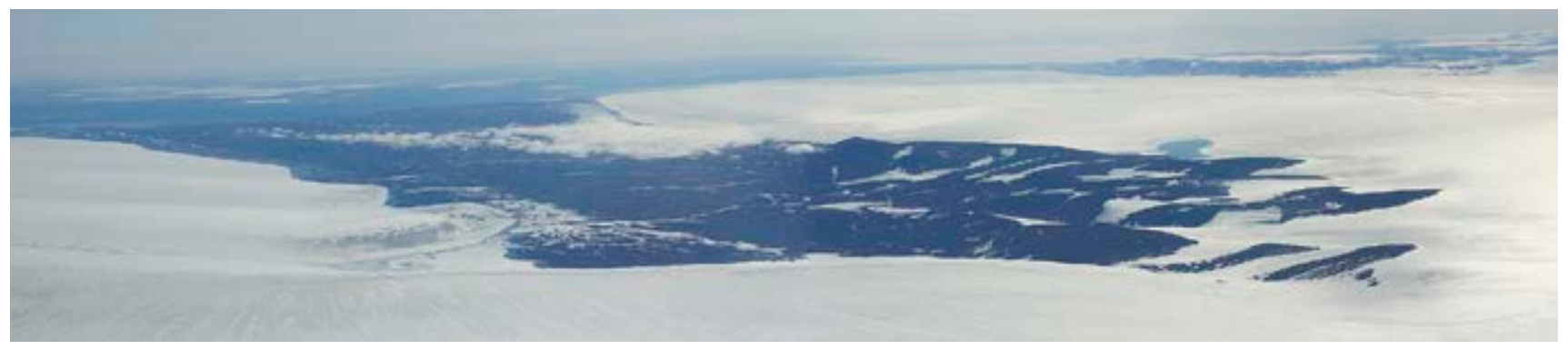

Fig. 2. Aerial view of Kilen, a key area for understanding the geology of the Wandel Sea Basin with exposures of Triassic to Cretaceous sediments. Kilen is approximately $10 \times 30 \mathrm{~km}$ large and is surrounded by glaciers except to the south-east that faces the Northeast Water polynya. View towards the south. For location see Fig. 1.

out in collaboration with GEUS (Christiansen et al. 2006; Gautier 2007; Gautier et al. 2011; Christiansen 2011). The seismic coverage of the North-East Greenland shelf is scattered and there are no wells. Therefore an understanding of the onshore geology is indispensable to construct analogues for the offshore basins. Geologists from Danish research institutions have worked in NE Greenland for over a century, and the accumulated sample and knowledge base at GEUS is the largest existing geological database for Greenland. In 2008, a project was set up at GEUS to systematise relevant available data and samples from this database, which contains results from onshore field work, core drilling and subsequent analyses. The aim was to use this material as a starting point for addressing key risks and uncertainties for future offshore exploration. Risks for offshore NE Greenland petroleum exploration include in broad terms: (1) the distribution, quality and correlation of the main Upper Jurassic - Lower Cretaceous source rock units, which have an important bearing on the nature of the petroleum products generated, (2) the nature and stratigraphic distribution of potential reservoir and seal rocks (and possible source rocks), primarily in the rather poorly known Cretaceous succession, which is very thick according to the only published seismic interpretation of the Danmarkshavn Basin (Hamann et al. 2005) and (3) the subsidence and exhumation history of North-East Greenland.

\section{Project portfolio}

In late 2007, a collaboration project, 'Petroleum Geological Studies, Services and Data in East and North-East Greenland', was initiated between GEUS and a number of oil companies. From the start, only little more than a handful of companies chose to participate, but soon the number grew to approximately twenty. The activity was designed with an open end, i.e. to continue for as long as industry interest would last, and it is now entering its seventh year. Participation is open to all companies that actively explore for and exploit petroleum. Upon entry into the group of partners, each company gets: (1) a GIS compilation summarising all available relevant information from North-East Greenland, including geological and palaeogeographical maps, data on $>17000$ samples, photographs, logs, potential field data, etc. from onshore North-East Greenland from $70^{\circ}$ to $82^{\circ} \mathrm{N}$, (2) three reports on 'Petroleum systems', 'Upliff' and 'Seabed Features' mainly based on existing knowledge but including some new and reprocessed data, (3) invitation to semi-annual workshops at GEUS of which the 12th took place in November 2013, (4) access to data, results, power point presentations, etc.

In addition, project partners are invited to participate in a number of projects dedicated to specific topics defined by GEUS. At the end of 2013, nine such projects, including a field excursion to North-East Greenland have been carried out, and an additional four new projects have recently been proposed (Table 1).

\section{Field work and shallow core drilling}

Onshore field work, often including shallow core drilling down to approximately $235 \mathrm{~m}$, has been carried out every summer since 2008 (Fig. 1). Each year's field campaign in North-East Greenland lasted 3-6 weeks and comprised 20-30 participants. An overview of the 2008 field season, including preliminary results of the drilling of the Blokelv-1 core hole was presented by Bojesen-Koefoed et al. (2009).

A principal target for shallow core drilling was the Upper Jurassic - Lower Cretaceous source rock succession, which is the local equivalent of the deposits that have generated the main part of the petroleum found in the North Sea and its northward extension. The imperfect knowledge of this succession was one of the key problems for assessment of the petroleum potential offshore North-East Greenland (Greenland Sea), and based on available outcrop samples the potential seemed surprisingly poor. Three cores with nearly $100 \%$ recovery and a total length of more than $600 \mathrm{~m}$ were 
Table 1. Overview of completed and proposed projects

\begin{tabular}{|c|c|c|c|}
\hline Project title & Initiated & Completed & Comments \\
\hline $\begin{array}{l}\text { Data package, Blokelv-1 core, } \\
\text { Jameson Land }\end{array}$ & Oct. 2008 & Dec. 2009 & $\begin{array}{l}\text { Oxfordian-Volgian portion of U. Jurassic - L. Cretaceous source } \\
\text { rock succession. Comprehensive sedimentological, stratigraphic } \\
\text { and source rock study }\end{array}$ \\
\hline $\begin{array}{l}\text { Provenance study of possible } \\
\text { reservoir sandstone units in East } \\
\text { and North-East Greenland }\end{array}$ & Oct. 2008 & Dec. 2010 & $\begin{array}{l}\text { Based on zircon ages and provenance sensitive minerals. } \\
\text { Comprehensive study of potential reservoir sandstone units, } \\
>200 \text { samples }\end{array}$ \\
\hline $\begin{array}{l}\text { Data package, Rødryggen-1 core, } \\
\text { Wollaston Forland }\end{array}$ & Mar. 2010 & Dec. 2010 & $\begin{array}{l}\text { Kimmeridgian-Ryazanian portion of U. Jurassic - L. Cretaceous source } \\
\text { rock succession. Comprehensive sedimentological, stratigraphical and } \\
\text { source rock study }\end{array}$ \\
\hline $\begin{array}{l}\text { North-East Greenland uplift history } \\
\text { phase II }\end{array}$ & Mar. 2010 & Nov. 2011 & Extension of initial uplift study to $78^{\circ} \mathrm{N}$ \\
\hline $\begin{array}{l}\text { The Cretaceous of North-East } \\
\text { Greenland }\end{array}$ & Jun. 2010 & Jun. 2012 & $\begin{array}{l}\text { Comprehensive study of the entire exposed and mostly poorly } \\
\text { known Cretaceous succession }\end{array}$ \\
\hline Geology of Store Koldewey & Dec. 2010 & Mar. 2012 & $\begin{array}{l}\text { Important area for understanding the Danmarkshavn Basin. } \\
\text { GIS compilation, including core-hole data }\end{array}$ \\
\hline $\begin{array}{l}\text { Data package, Brorson Halvø-1 core, } \\
\text { Wollaston Forland }\end{array}$ & Apr. 2011 & Dec. 2011 & $\begin{array}{l}\text { Kimmeridgian-Ryazanian portion of U. Jurassic - L. Cretaceous } \\
\text { source rock succession in different tectonic settings. Comprehensive } \\
\text { sedimentological, stratigraphic and source rock study }\end{array}$ \\
\hline $\begin{array}{l}\text { Data package, Nanok-1 core, } \\
\text { Hold with Hope }\end{array}$ & Nov. 2011 & Nov. 2012 & $\begin{array}{l}\text { Poorly exposed Cenomanian-Turonian succession } \\
\text { Comprehensive sedimentological, stratigraphic and source rock study }\end{array}$ \\
\hline $\begin{array}{l}\text { The Triassic of the Wandel Sea Basin } \\
\text { The Jurassic-Cretaceous of the } \\
\text { Wandel Sea Basin }\end{array}$ & $\begin{array}{l}\text { Pending } \\
\text { Pending }\end{array}$ & & $\begin{array}{l}\text { Also highly relevant for Barents Sea geology } \\
\text { Also highly relevant for Barents Sea geology }\end{array}$ \\
\hline $\begin{array}{l}\text { The tectonic evolution of the } \\
\text { Wandel Sea Basin }\end{array}$ & Pending & & Also highly relevant for Barents Sea geology \\
\hline $\begin{array}{l}\text { Northern East Greenland uplift history } \\
\text { - focus on the Wandel Sea Basin }\end{array}$ & Pending & & Extension of previous uplift studies to $83^{\circ} \mathrm{N}$ and northwards \\
\hline
\end{tabular}

collected, covering the full stratigraphy from the Oxfordian to the Ryazanian (Blokelv-1, Rødryggen-1 and Brorson Halvø-1). More than 600 samples were analysed for petroleum potential and numerous biological marker and isotopic analyses carried out. Integrated with detailed stratigraphic and sedimentological studies they provide a unique insight into the character and development of the succession. Based on these studies, it has been demonstrated that the petroleum potential is $2-3$ times higher than expected from initial data and that the succession, contrary to previous beliefs, is complete with only local hiatuses in specific tectonic settings. Core drilling has also been carried out in unexposed intervals of the Cretaceous (Store Koldewey-1, Nanok-1), and in the Triassic (Dunken-1, 2) and Permian successions (Kim Fjelde-1) of Peary Land.

Traditional onshore field work focused on solving predefined problems related to the overall key risks and uncertainties listed in the foregoing. Each season, individual field teams dedicated most of their efforts to one of the various projects (Table 1), while also contributing to other projects where needed. For instance, although both sand provenance and uplift studies were carried out with dedicated field teams, all teams collected samples for mineralogical analysis, apatite fission track analysis (AFTA) and vitrinite reflectance analysis $\left(R_{o}\right)$, ensuring proper geographical and stratigraphic coverage. A small degree of overlap between some projects exists.
For instance, the Store Koldewey study was concentrated in a restricted geographical area, but included deposits ranging from Caledonian basement to Pleistocene mud and elements of uplift studies, sand provenance, etc. as integral parts of the study. In contrast, the Cretaceous study concerned a specific, poorly known, portion of the stratigraphic column with scattered outcrops over a huge area (including Store Koldewey). The study was divided into sub-projects such as the erection of a formal and consistent lithostratigraphy, an integrated biostratigraphy that included macrofossils, microfossils (palynomorphs), reservoir model studies, petroleum source rock studies and more.

\section{Published Research}

Generally, all results produced during the course of the project are subject to a five-year confidentiality clause that must expire before GEUS can publish detailed results. However, general observations of little or no relevance for the proprietary studies have been published and more are under way. These include studies of igneous rocks (Larsen et al. 2013, in press), coal deposits (Bojesen-Koefoed et al. 2012; Petersen et al. 2013), Palaeogene sediments (Nøhr-Hansen et al. 2011), stratigraphy and palaeoenvironments (Alsen \& Mutterlose 2009; Nøhr-Hansen 2012; Pauly et al. 2012a, b, 2013) and integrated studies (Fyhn et al. 2012). A large number of pa- 
pers by GEUS scientists are expected in the coming years as confidentiality expires.

\section{Impact on offshore petroleum exploration and perspectives for the future}

A better understanding of numerous critical parameters has been achieved, and many of the results have had a strong influence on the development of offshore exploration models. In particular, based on the onshore work a better understanding of source rock distribution, thickness and quality as well as the timing and magnitude of subsidence and uplift have been obtained. In addition, a detailed understanding of the Cretaceous succession will be very important for evaluating future prospects and for correlation when offshore core holes and wildcat wells are eventually drilled.

In recent years, the focus of onshore field activities has shifted northwards, where the deposits of the Wandel Sea Basin (Fig. 1) are important for the understanding of the geology of the northernmost portion of the licence area off North-East Greenland. The northern region is also important for understanding the geology of the Barents Sea shelf, which is an area under intense exploration. Hence, a gradual shift of focus towards the conjugate margin is expected to take place in the coming years.

The nature of the collaboration with the industry in North-East Greenland must be expected to change after allocation of licences. Companies holding licences may change their focus whereas others not holding licences are expected to downgrade their interests in the region. However, GEUS sees an obvious interest in a continued collaboration, since it provides a platform for studies that would otherwise be beyond the economic capacity of the institution, but which are nonetheless important elements of the raison d'être of a geological research institution.

\section{References}

Alsen, P. \& Mutterlose, J. 2009: The Early Cretaceous of North-East Greenland: A crossroads of belemnite migration. Palaeogeography, Palaeoclimatology, Palaeoecology 280, 168-182.

Bojesen-Koefoed, J.A., Bjerager, M. \& Piasecki, S. 2009: Shallow core drilling and petroleum geology related field work in North-East Greenland 2008. Geological Survey of Denmark and Greenland Bulletin 17, 53-56.

Bojesen-Koefoed, J.A., Kalkreuth, W., Petersen, H.I. \& Piasecki, S. 2012: A remote coal deposit revisited: Middle Jurassic coals at Kulhøj, western Germania Land, northeast Greenland. International Journal of Coal Geology 98, 50-61.
Christiansen, F.G. 2011: Greenland petroleum exploration: history, breakthroughs in understanding and future challenges. Memoir of the Geological Society (London) 35, 647-661.

Christiansen, F.G., Gautier, D.L., Stemmerik, L., Bidstrup, T., BojesenKoefoed, J.A. \& Sørensen, K. 2006: Petroleum resource potential of the East Greenland shelf. AAPG Hedberg Research Conference on Understanding World Oil Resources, Colorado Springs, Colorado, USA, 12-17 November 2006. Extended abstract, poster.

Fyhn, M.B.W., Rasmussen, T.M., Dahl-Jensen, T., Weng, W.L., BojesenKoefoed, J.A. \& Nielsen, T. 2012: Geological assessment of the East Greenland margin. Geological Survey of Denmark and Greenland Bulletin 26, 61-64.

Gautier, D.L. 2007: Assessment of undiscovered oil and gas resources of the East Greenland Rift Basins Province. U.S. Geological Survey Fact Sheet 2007-3077, 4 pp.

Gautier, D.L., Stemmerik, L., Christiansen, F.G., Sørensen, K., Bidstrup, T., Bojesen-Koefoed, J.A., Bird, K.J., Charpentier, R.R., Houseknecht, D.W., Klett, T.R., Schenck, C.J. \& Tennyson, M.E. 2011: Assessment of NE Greenland: prototype for development of Circum-Arctic resource appraisal methodology. Memoir of the Geological Society (London) 35, 663-672.

Hamann, N.E., Whittaker, R.C. \& Stemmerik, L. 2005: Geological development of the Northeast Greenland Shelf. In: Doré, A.G. \& Vining, A.A. (eds): Petroleum geology: North-West Europe and global perspectives. Proceedings of the 6th Petroleum Geology Conference, 887-902. London: Geological Society.

Larsen, L.M., Pedersen, A.K., Sørensen, E.V., Watt, W.S. \& Duncan, R.A. 2013: Stratigraphy and age of the Eocene Igtertivâ Formation basalts, alkaline pebbles and sediments of the Kap Dalton Group in the graben at Kap Dalton, East Greenland. Bulletin of the Geological Society of Denmark 61, 1-18.

Larsen, L.M., Pedersen, A.K., Tegner, C. \& Duncan, R.A. in press: Eocene to Miocene igneous activity in NE Greenland: northward younging of magmatism along the East Greenland margin. Journal of the Geological Society (London), http://dx.doi.org/10.1144/jgs2013-118

Nøhr-Hansen, H. 2012: Palynostratigraphy of the Cretaceous - lower Palaeogene sedimentary succession in the Kangerlussuaq Basin, southern East Greenland. Review of Palaeobotany and Palynology 178, 59-90.

Nøhr-Hansen, H., Nielsen, L.H., Sheldon, E., Hovikoski, J. and Alsen, P. 2011: Palaeogene deposits in North-East Greenland. Geological Survey of Denmark and Greenland Bulletin 23, 61-64.

Pauly, S., Mutterlose, J. \& Alsen, P. 2012a: Lower Cretaceous (upper Ryazanian-Hauterivian) chronostratigraphy of high latitudes (NorthEast Greenland). Cretaceous Research 34, 308-326.

Pauly, S., Mutterlose, J. \& Alsen, P. 2012b: Early Cretaceous palaeoceanography of the Greenland-Norwegian Seaway evidenced by calcareous nannofossils. Marine Micropaleontology 90-91, 72-85.

Pauly, S., Mutterlose, J. \& Alsen, P. 2013: Depositional environments of Lower Cretaceous (Ryazanian-Barremian) sediments from Wollaston Forland and Kuhn Ø, North-East Greenland. Bulletin of the Geological Society of Denmark 61, 19-36.

Petersen, H.I, Øverland, J.A., Solbakk T., Bojesen-Koefoed, J.A. \& Bjerager, M. 2013: Unusual resinite-rich coals found in northeastern Greenland and along the Norwegian coast: Petrographic and geochemical composition. International Journal of Coal Geology 109-110, 58-76.

Authors' address
Geological Survey of Denmark and Greenland, ØsterVoldgade 10, DK-1350 Copenhagen K, Denmark. E-mail: jbk@geus.dk. 